\title{
RUBRIC AND PERFORMANCE-BASED ASSESSMENT
}

\author{
Xue Bai, Virginia State University, xbai@vsu.edu \\ Yaquan Xu, Georgia Gwinnett College, Lawrenceville, GA, USA \\ Fidelis Ikem, Albany State University, fidelis.ikem@asurams.edu
}

\begin{abstract}
This paper describes the design and implementation of a program outcomes assessment process for the Computer Information Systems Program at a medium-sized university to meet the ABET accreditation requirements. The purpose of the assessment process is to collect and analyze information on student performance to detect any shortfalls in the program and to formulate and implement corrective actions to improve the learning outcomes. Assessment results from fall 2007 to spring 2009 indicated that a relatively small percentage of students achieve some of the program outcomes. The rubrics assessments and student survey help to identify the shortfalls of the program and detect the areas for improvement. After making adjustments to the curriculum, assessment results for some learning outcomes indicated that the vast majority of students achieved all the program outcomes
\end{abstract}

Keywords: learning outcomes, rubrics assessments and ABET

\section{INTRODUCTION}

Assurance of learning outcomes is integral to fulfilling the teaching and learning mission of higher education. The effective assessment provides a mechanism to ascertain how well a program is achieving its stated learning outcomes, to detect any shortfalls in the program and to formulate and implement corrective actions to improve student learning and the effectiveness of the curriculum, and to meet the ABET accreditation requirements. In an effort to promote the quality of academic programs in higher education institution, external accrediting organizations have shifted focus from a teacher-centered "instruction paradigm" to a student centered "learning paradigm"(Barr and Tagg 1995, Butnard 1999, Taylor 2000,). The assessments have moved towards evaluating of learning outcomes against objectives, identifying possible improvement, and closing the loop. According to Rogers (Rogers 2003), the primary outcome assessment question is "Can students demonstrate the ability to perform at an acceptable level?" and program assessment is a means through which evidence is provided that students are able to demonstrate "knowledge or skill directly linked to specific program outcomes". The American Association for Higher Education identified nine principles of good assessment, "True assessment begins with educational values driving what we choose to assess and how we choose to perform assessment and it is through assessment that we meet our responsibilities to our students and the public"(Education 1991). Some of the external accrediting organizations have established standards for assessments. For example, The Association to Advance Collegiate Schools of Business (AACSB) has set requirements for the assessment of learning, which is labeled as "assurance of learning," that cover all business-oriented courses within collegiate business schools(AACSB 2005). The Accrediting Board of Engineering Technologies (ABET) is another accrediting organizations that became the recognized agency for evaluating and accrediting information systems programs in 2001. Their review process includes an examination of eight standards. The first standard focuses on a program's objectives and assessments (Rogers 2003). The divergence between two accrediting bodies is that the AACSB standards contain relatively more prescription of management process, while the ABET standards contain relatively more prescription of course content (Hilton and Lo 2007).

In the following sections, we will describe the program assessment practice using rubric assessment methodology undertaken for the four semesters in 2007, 2008 and 2009 at the Computer Information Systems Department for the ABET accreditation. The data collected from the rubrics assessments and student survey are analyzed to improve the student learning outcomes and to evaluate the effectiveness of the Computer Information Systems program.

\section{ASSESSMENT PLAN}




\section{Issues in Information Systems \\ Volume 14, Issue 2, pp.1-11, 2013}

ABET accreditation requires a program to be assessed must implement the assessment process for program educational objectives and student outcomes. To demonstrate a continuous improvement loop, the assessment data including student sample work are collected and analyzed. Most importantly, demonstrate how the results are utilized to identify and implement program improvement. In response to ABET requirements regarding program outcomes and assessment, we have developed an overall assessment plan to measure program outcomes. The assessment plan includes the following seven assessment steps:

1. Establish program goals and objectives

2. Develop learning outcomes and performance criteria

3. Define curriculum map with outcomes and performance criteria

4. Choose appropriate evaluate methods for difference courses

5. Determine when, how, and where the type of data would be collected and evaluated

6. Develop a process for evaluation and feedback

7. Use assessment results to support recommendations for change

Learning outcomes must be in line with the institution's mission. Each of the outcomes in the course rubrics is derived from the department learning goals and describes significant and essential learning that learners have achieved, and can reliably demonstrate at the end of a course. Figure 1 shows the hierarchical structure the learning outcome pyramid.

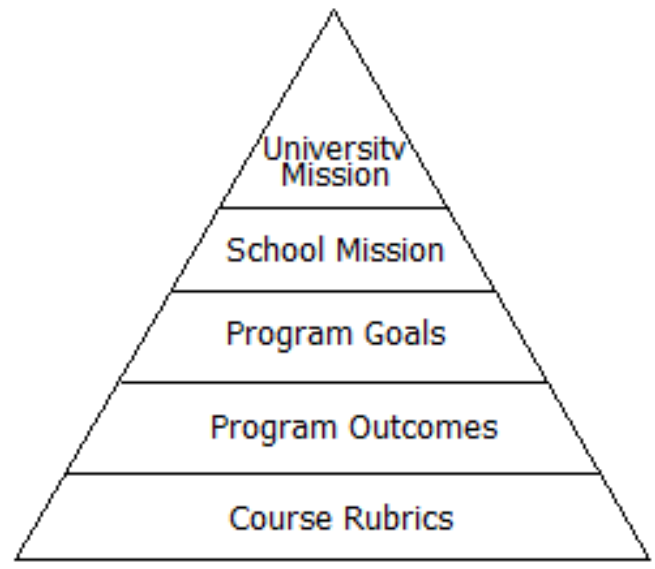

Figure 1: Outcomes pyramid

\section{PROGRAM OBJECTIVES AND OUTCOMES}

Program objectives describe what graduates are expected to attain after graduation. Program educational objectives are based on the needs of the program's constituencies. While student outcomes describe what students are expected to know and be able to do. Learning outcomes are related to the knowledge, skills, and behaviors that students acquire as they progress through the program. Program objectives are evaluated and measured through the assessment of the learning outcomes. Assessment of learning outcomes is the process to identify, collect, and prepare data to evaluate the attainment of student outcomes, and the results are used to evaluate the program educational objectives. The critical aspect of any assessment is to identify what is to be assessed. In an educational institution, what to be assessed are the learning goals of a program. From an accreditation standpoint, assessment includes the evaluation of the knowledge, skills, and abilities the individual student possesses and can demonstrate upon completion of their educational program(Murray, Pérez et al. 2008). For the ABET accreditation process, it revolves around program objectives and outcomes. Objectives are long-term goals that academic institution set for 


\section{Issues in Information Systems \\ Volume 14, Issue 2, pp.1-11, 2013}

students, while outcomes are those skills and abilities the academic institution expects students to have when they finish their educational program. Learning outcomes often begin with the phrase "Students will be able to."

We developed four objectives and eight outcomes for the CIS program. A detail set of objectives are presented in Table 1, and a complete set of learning outcomes is depicted in Table 2.

Table 1: Learning Goals

\begin{tabular}{|l|l|}
\hline Learning objective 1 & $\begin{array}{l}\text { To prepare students with knowledge, skills and techniques in information systems } \\
\text { practice }\end{array}$ \\
\hline Learning objective 2 & To prepare students to successfully serve on teams \\
\hline Learning objective 3 & To prepare students with effective communication skills \\
\hline Learning objective 4 & To prepare students to recognize the ethical and professional responsibilities \\
\hline
\end{tabular}

Table 2: Learning Outcomes

\begin{tabular}{|l|l|}
\hline Learning Outcome 1 & Students will be able to obtain quantitative, modeling \& analytical knowledge \\
\hline Learning Outcome 2 & Students will be able to view problems and problem-solving from a system approach \\
\hline Learning Outcome 3 & Students will acquire essential programming skills \\
\hline Learning Outcome 4 & Students will learn current information technology issues and trends \\
\hline Learning Outcome 5 & Students will be able to work effectively on teams to accomplish a common goal \\
\hline Learning Outcome 6 & Students will be able to express effectively in oral communication \\
\hline Learning Outcome 7 & Students will be able to express effectively in written communication \\
\hline Learning Outcome 8 & $\begin{array}{l}\text { Students will be able to understand professional ethical, legal, security and social } \\
\text { issues and responsibilities }\end{array}$ \\
\hline
\end{tabular}

At the end of each semester, we assess how well our students meet these objectives and outcomes, and use the results of this assessment to improve the program.

To meet the requirements of the ABET accreditation, learning outcomes have been developed to map the learning goals of the department, and then rubrics measuring the learning outcomes have been developed for each course. The assessment plan includes a mix of direct and indirect measures of program outcomes. The direct measure is a scoring rubric for each course, which is done by faculty member by the end of each semester; the indirect measure is the end-of-course student surveys. To ensure our assessments meet the ABET accreditation requirements, we listed all of our program outcomes which were adopted from ABET's outcomes for applied computer program, plus those specific to our program, and then we developed multiple assessment measures for each outcome, instead of relying on a single assessment measure per outcome. The following table gives an example of the rubrics for the Web Application Design and Implementation course.

\section{CISY466 Web Application Design and Implementation}

CIS Performance Criteria Evaluation

Outcome: Students will be able to solve problems by applying a systematic approach

\begin{tabular}{|c|c|c|c|c|c|}
\hline & $\begin{array}{c}\text { Beginning } \\
1\end{array}$ & $\begin{array}{c}\text { Developing } \\
2\end{array}$ & $\begin{array}{c}\text { Accomplished } \\
3\end{array}$ & $\begin{array}{c}\text { Exemplary } \\
4\end{array}$ & Level \\
\hline $\begin{array}{l}\text { Know the system } \\
\text { development process }\end{array}$ & $\begin{array}{l}\text { Does not know } \\
\text { the system } \\
\text { development } \\
\text { process }\end{array}$ & $\begin{array}{l}\text { Know very little } \\
\text { about the system } \\
\text { development } \\
\text { process }\end{array}$ & $\begin{array}{l}\text { Know the main } \\
\text { part of the } \\
\text { system } \\
\text { development } \\
\text { process }\end{array}$ & $\begin{array}{l}\text { Know the whole } \\
\text { system } \\
\text { development } \\
\text { process }\end{array}$ & \\
\hline $\begin{array}{l}\text { Apply systems design } \\
\text { knowledge, techniques }\end{array}$ & $\begin{array}{l}\text { Does not know } \\
\text { how to apply }\end{array}$ & $\begin{array}{l}\text { Be able to apply } \\
\text { some systems }\end{array}$ & $\begin{array}{l}\text { Be able to apply } \\
\text { most of the }\end{array}$ & $\begin{array}{l}\text { Correctly apply } \\
\text { all the systems }\end{array}$ & \\
\hline
\end{tabular}




\section{Issues in Information Systems}

Volume 14, Issue 2, pp.1-11, 2013

\begin{tabular}{|l|l|l|l|l|l|}
\hline and skills & systems design & design & systems design & design & \\
& knowledge, & knowledge, & knowledge, & knowledge, \\
& techniques, and & techniques, and & techniques, and & techniques, and \\
& skills & skills learned & skills learned & skills learned & \\
\hline
\end{tabular}

Outcome: Students will acquire essential programming skills

\begin{tabular}{|c|c|c|c|c|c|}
\hline & $\begin{array}{c}\text { Beginning } \\
1\end{array}$ & $\begin{array}{c}\text { Developing } \\
2\end{array}$ & $\begin{array}{c}\text { Accomplished } \\
3\end{array}$ & $\begin{array}{c}\text { Exemplary } \\
4\end{array}$ & Level \\
\hline $\begin{array}{l}\text { Understand written } \\
\text { programs }\end{array}$ & $\begin{array}{l}\text { Does not } \\
\text { understand } \\
\text { written programs }\end{array}$ & $\begin{array}{l}\text { Understand a } \\
\text { little part of } \\
\text { written programs }\end{array}$ & $\begin{array}{l}\text { Understand most } \\
\text { part of written } \\
\text { programs }\end{array}$ & $\begin{array}{l}\text { Completely } \\
\text { understand } \\
\text { written programs }\end{array}$ & \\
\hline Design programs & $\begin{array}{l}\text { Does not know } \\
\text { how to design } \\
\text { programs }\end{array}$ & $\begin{array}{l}\text { Programs } \\
\text { designed is not } \\
\text { executable }\end{array}$ & $\begin{array}{l}\text { Programs } \\
\text { designed is } \\
\text { executable but } \\
\text { not efficient }\end{array}$ & $\begin{array}{l}\text { Design } \\
\text { executable and } \\
\text { efficient } \\
\text { programs } \\
\end{array}$ & \\
\hline Write correct codes & $\begin{array}{l}\text { Does not know } \\
\text { how to write } \\
\text { codes }\end{array}$ & $\begin{array}{l}\text { Have many bugs } \\
\text { in codes }\end{array}$ & $\begin{array}{l}\text { Have only a few } \\
\text { bugs in codes }\end{array}$ & $\begin{array}{l}\text { Write correct } \\
\text { structured codes }\end{array}$ & \\
\hline $\begin{array}{l}\text { Execute, test and debug } \\
\text { programs }\end{array}$ & $\begin{array}{l}\text { Does not know } \\
\text { how to execute, } \\
\text { test and debug } \\
\text { programs }\end{array}$ & $\begin{array}{l}\text { Know basic steps } \\
\text { in execute, test } \\
\text { and debug } \\
\text { programs, but } \\
\text { make some errors }\end{array}$ & $\begin{array}{l}\text { Make a few } \\
\text { errors in execute, } \\
\text { test and debug } \\
\text { programs }\end{array}$ & $\begin{array}{l}\text { Correctly } \\
\text { execute, test and } \\
\text { debug programs }\end{array}$ & \\
\hline
\end{tabular}

Outcome: Students will be able to work effectively on teams to accomplish a common goal

\begin{tabular}{|c|c|c|c|c|c|}
\hline & $\begin{array}{c}\text { Beginning } \\
1\end{array}$ & $\begin{array}{c}\text { Developing } \\
2\end{array}$ & $\begin{array}{c}\text { Accomplished } \\
3\end{array}$ & $\begin{array}{c}\text { Exemplary } \\
4\end{array}$ & $\overline{\text { Level }}$ \\
\hline Fulfill team role's duties & $\begin{array}{l}\text { Do not perform } \\
\text { any duties of } \\
\text { assigned team } \\
\text { role }\end{array}$ & $\begin{array}{l}\text { Perform very little } \\
\text { duties }\end{array}$ & $\begin{array}{l}\text { Perform nearly } \\
\text { all duties }\end{array}$ & $\begin{array}{l}\text { Perform all } \\
\text { duties of } \\
\text { assigned team } \\
\text { role }\end{array}$ & \\
\hline Listen to other teammates & $\begin{array}{l}\text { Is always } \\
\text { talking-never } \\
\text { allows anyone } \\
\text { else to speak }\end{array}$ & $\begin{array}{l}\text { Usually doing } \\
\text { most of the } \\
\text { talking-rarely } \\
\text { allows others to } \\
\text { speak }\end{array}$ & $\begin{array}{l}\text { Listens, but } \\
\text { sometimes talks } \\
\text { too much }\end{array}$ & $\begin{array}{l}\text { Listens and } \\
\text { speaks a fair } \\
\text { amount }\end{array}$ & \\
\hline
\end{tabular}

\section{ASSESSMENT METHOD AND IMPLEMENTATION OF ASSESSMENT}

Assessment is continuous processes to identify, collect, and prepare data to evaluate the attainment of student outcomes. Assessment employs direct or indirect measures as appropriate to the outcomes to be measured. After having developed learning objectives and outcomes, the next step is to map a type of assessment to different information systems courses. The selection of a particular type of assessment depends on the nature of the course. For example, in an introductory course on CIS (Introduction to IS), the student homework are assessed; while in a capstone project courses Current Issue in IS), programming skills, teamwork, oral presentation, and technical writing are assessed.

Once the mapping was complete, we developed a set of performance criteria and rubrics for the assessment purpose. Gloria Rogers, the ABET director of assessment define the performance criteria as "Specific, measurable statements identifying the performances required to meet the outcome; confirmable through evidence" (Rogers). First, we broke learning outcomes to one or more objectively measurable performance criteria, then a standard set of scoring rubrics was developed to articulate specific criteria to be used in evaluating student's achievement of each learning outcome. 


\section{Issues in Information Systems \\ Volume 14, Issue 2, pp.1-11, 2013}

Petkov and petkova(Petkov and Petkova 2006) have suggested the use of standardized rubrics with the same number of criteria to evaluate different courses within an IS program. The use of standardized rubrics in different course is called as the "absolute comparison mode". The absolute comparison mode allows the assessors to draw conclusions about whether students in a particular course have scored better or worse than those in another course with respect to the same criterion.(Petkova, D’Onofrio et al. 2009) .

In the fall semester 2007, the ABET Accreditation Committee has reviewed policies, procedures, and criteria that are pertaining to ABET accreditation. Based on the ABET accreditation requirements, the committee conducted intensive discussion at departmental meetings and then developed CIS program objectives (Table 1), outcomes (Table 2), and performance criteria (Appendix 1). Meanwhile, the committee developed template of the course description (Appendix 2) as a part of the documentation requirements for the ABET accreditation. Based on the objectives and course descriptions, assessment methods have been developed for each course that are in line with AOL assessment methodology. These assessment methods are specifically designed to assess a specific ABET learning outcomes and require students to make use of the ability defined in the outcomes.

In order to provide the same baseline and so we can perform more accurate analysis of improvement, the combination of the assessment methods for each course must be similar in scope and difficulty. In addition, the instructor should be aware of previous assessment methods and problems used in the same course for the same outcome, and try to achieve a similar level of difficulty. Those assessment methods are summarized in the following table: 


\section{Issues in Information Systems}

Volume 14, Issue 2, pp.1-11, 2013

Table 3: Assessment Methods for Each Assessed Course

\begin{tabular}{|l|l|r|r|r|r|r|r|r|r|r|r|r|r|r|}
\hline \multirow{2}{*}{ Course } & \multirow{2}{*}{$\begin{array}{l}\text { Course } \\
\text { Name }\end{array}$} & \multicolumn{6}{|l|}{ Assessment Methods Used } \\
\hline & & $\mathrm{A}$ & $\mathrm{B}$ & $\mathrm{C}$ & $\mathrm{D}$ & $\mathrm{E}$ & $\mathrm{F}$ & $\mathrm{G}$ & $\mathrm{H}$ & $\mathrm{I}$ & $\mathrm{J}$ & $\mathrm{K}$ & $\mathrm{L}$ & $\mathrm{M}$ \\
\hline CISY 155 & & $\mathrm{X}$ & $\mathrm{X}$ & $\mathrm{X}$ & $\mathrm{X}$ & & & & & & & & & $\begin{array}{c}\mathrm{X} \\
1\end{array}$ \\
\hline CISY 330 & & $\mathrm{X}$ & & $\mathrm{X}$ & $\mathrm{X}$ & & $\mathrm{X}$ & & & & & & & \\
\hline CISY 260 & & $\mathrm{X}$ & & $\mathrm{X}$ & $\mathrm{X}$ & & & & & & & & & \\
\hline CISY 363 & & $\mathrm{X}$ & & $\mathrm{X}$ & $\mathrm{X}$ & & & & & & & & & $\mathrm{X}$ \\
\hline CISY 365 & & $\mathrm{X}$ & & $\mathrm{X}$ & $\mathrm{X}$ & & & & & & & & & $\mathrm{X}$ \\
\hline CISY 350 & & $\mathrm{X}$ & $\mathrm{X}$ & $\mathrm{X}$ & $\mathrm{X}$ & $\mathrm{X}$ & & & & & & & & \\
\hline CISY 305 & & $\mathrm{X}$ & & $\mathrm{X}$ & $\mathrm{X}$ & & & & & & & & & $\mathrm{X}$ \\
\hline CISY 311 & & $\mathrm{X}$ & & $\mathrm{X}$ & $\mathrm{X}$ & & & & & & & & & $\mathrm{X}$ \\
\hline CISY 344 & & $\mathrm{X}$ & $\mathrm{X}$ & $\mathrm{X}$ & $\mathrm{X}$ & & & & & & & & & \\
\hline CISY 362 & & $\mathrm{X}$ & $\mathrm{X}$ & $\mathrm{X}$ & $\mathrm{X}$ & & & & & & & & & \\
\hline CISY 444 & & $\mathrm{X}$ & $\mathrm{X}$ & $\mathrm{X}$ & $\mathrm{X}$ & & & & & & & & & \\
\hline CISY 464 & & & & & & & & & & & & & & \\
\hline CISY 466 & & $\mathrm{X}$ & $\mathrm{X}$ & $\mathrm{X}$ & $\mathrm{X}$ & & & & & & & & & \\
\hline CISY 467 & & $\mathrm{X}$ & $\mathrm{X}$ & $\mathrm{X}$ & $\mathrm{X}$ & & & & & & & & & \\
\hline CISY 480 & & $\mathrm{X}$ & $\mathrm{X}$ & $\mathrm{X}$ & $\mathrm{X}$ & & & & & & & & & \\
\hline CISY 486 & & $\mathrm{X}$ & $\mathrm{X}$ & $\mathrm{X}$ & $\mathrm{X}$ & & & & & & & & & \\
\hline CISY 495 & & $\mathrm{X}$ & $\mathrm{X}$ & $\mathrm{X}$ & $\mathrm{X}$ & $\mathrm{X}$ & & & & & & & \\
\hline
\end{tabular}

A-Homework; B-Projects; C-Exams; D-Quizzes; E-Oral report; F-Laboratory reports; G-Students survey; HFaculty evaluations; I-Exit interviews; J- Senior assignment evaluations; K- Peer evaluations;

L-Classroom participation; M-Written Assignment.

${ }^{1}$ It is only for CISY 155 honor section

Faculty members will collect the assessment data for each of the listed courses by using the assessment methods. Based on the assessment data, faculty members score rubric for each course. Meanwhile, students' survey is used to collect data to indirectly measure the learning outcomes. Appendix 3 is a sample of student survey.

\section{RESULTS AND DISCUSSION}

Assessment is a continuous process and should occur periodically and consistently and at the program level with enough frequency to be effective as a means for driving program improvement(Murray, Pérez et al. 2008). We have collected assessment data for all the IS courses at the end of each semester since Fall 2007. The assessment data have both direct and indirect measures to evaluate the learning outcomes. As mentioned earlier, the direct measure is a scoring rubric for each course, which is done by faculty member by the end of each semester; the indirect measure 


\section{Issues in Information Systems \\ Volume 14, Issue 2, pp.1-11, 2013}

is the end-of-course student surveys. The rubric measures are based on the assessment data collected through the semester with the appropriate assessment methods as specified in Table 3. Bothe rubrics and student survey are analyzed to evaluate the effectiveness of the curriculum and used for program improvement planning purpose for the following academic year. Figure 2 illustrates the student survey relevant to the learning outcomes.

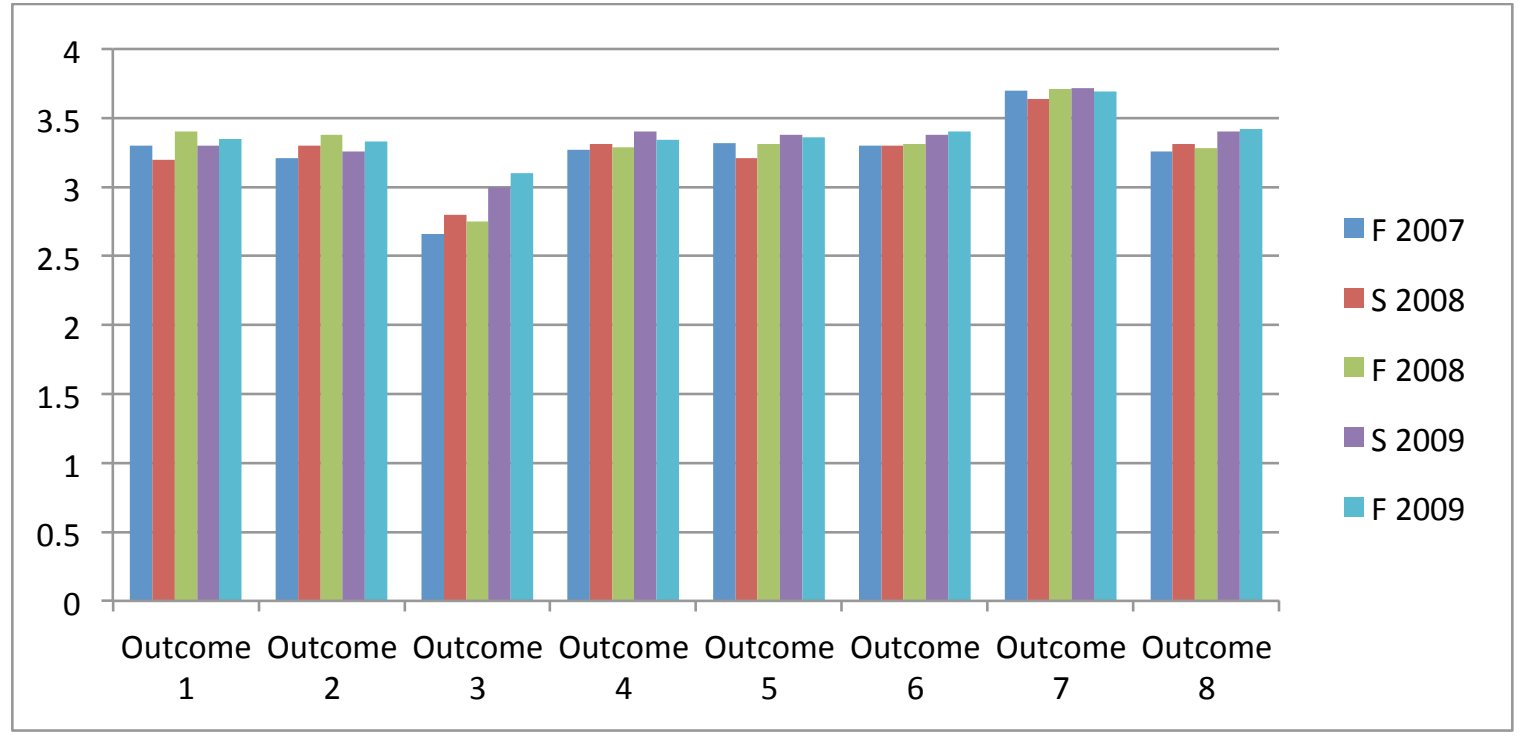

Figure 2: Student Survey on Learning Outcomes

The student survey data are compared with the faculty's rubrics assessment and we concluded that the average score of outcome 3: Students will acquire essential programming skills, is much lower than other outcomes. After detecting the shortfalls of the program, we looked into the problem with more details on the students responses on the survey questions. We found that most students agreed that they had hard time to use flow chart/pseudo code to design programs for a given application problems and they did not know how to deal with the syntax and logical errors. Based on our findings, the instructors integrated the pseudo code lectures and debugging into their programming courses, and change their teaching style and assessment methods accordingly to make sure that student would better grasp the knowledge and skills. As is shown in Figure 2, in the following semesters, not only the average score of outcome 3 is significantly improved.

\section{CONCLUSIONS}

In this paper, we discussed the details of the rubric assessment of the learning outcomes including how the rubrics were developed and applied to reflect the leaning goals of the program, how the data were collected, how the data were used to assess the effectiveness of the program, and to explore the suitability of these methodologies for the program accreditation. We also discussed the assessment loop developed at Computer Information Systems Department and how the rubric assessment data were applied to close the loop. We presented an example in great details to show to explain how we use the assessment criteria to find out the weakness of the program and make improvement. We believe the assessment loop proposed would be a good reference for the other CIS or related programs which pursue accreditation or improvement.

\section{REFERENCES}

1. AACSB. (2005). "Eligibility Procedures and Accreditation Standards for Business Accreditation." from http://www.aacsb.edu/accreditation/business/AACSBSTANDARDS-Jan05-Final.pdf.

2. Barr, R. B. and J. Tagg (1995). "From Teaching to Learning: A New Paradigm Shift for Undergraduate Education." Change: 12-25. 


\section{Issues in Information Systems}

Volume 14, Issue 2, pp.1-11, 2013

3. Education, A. A. f. H. (1991). Nine Principles of Good Practice for Assessing Student Learning, Sterling, VA: Stylus.

4. Hilton, T. S. and W. N. Lo (2007). "IS accreditation in AACSB colleges via ABET." Journal of the Association for Information Systems 8(1): 1-15.

5. Murray, M., J. Pérez, et al. (2008). "A Model for Using a Capstone Experience as One Method

6. of Assessment of an Information Systems Degree Program." Journal of Information Systems Education 19(2): 197-208.

7. Petkov, D. and O. Petkova (2006). "Development of Scoring Rubrics for Projects as an assessment Tool across an IS Program." Issues in Informing Science and Information Technology (3): 499-509.

8. Petkova, O., M. D’Onofrio, et al. (2009). "Using Projects Scoring Rubrics to Assess Student Learning in an Information Systems Program." Journal of Information Systems Education 19(2): 241-251.

9. Rogers, G. "The Language of Assessment: Humpty Dumpty Had a Great Fall..." from http://www.abet.org/Linked\%20Documents-UPDATE/Assessment/Assessment\%20Tips3.pdf.

10. Rogers, G. (2003). Do Grades Make the Grade for Program Assessment? Assessment Tips with Gloria Rogers. Communications Link, ABET, Inc.

11. Rogers, G. and J. Sando. (1997). "Stepping Ahead: An Assessment Plan Development Guide." from https://www.howard.edu/assessment/open/Tools/PlanningGuide/assessment.htm.

12. Wisconsin, U. o. (1998). from http://www.provost.wisc.edu/assessment/Assessmentplan2003_R2008.pdf.

\section{Appendix 1: Performance Criteria}

\begin{tabular}{|c|c|c|c|}
\hline \multicolumn{4}{|c|}{$\begin{array}{l}\text { Performance Criteria: specific, measurable statements identifying the performances required to meet the outcome; } \\
\text { confirmable through evidence. }\end{array}$} \\
\hline \multicolumn{4}{|l|}{ I: Instruction is provided in the course } \\
\hline \multicolumn{4}{|l|}{ A: Applied in the course } \\
\hline \multicolumn{4}{|l|}{ P: Mentioned in the course } \\
\hline $\begin{array}{c}\text { Performance Criteria } \\
\end{array}$ & I & $\mathbf{A}$ & $\mathbf{P}$ \\
\hline $\begin{array}{l}\text { Outcome: Students will be able to acquire } \\
\text { quantitative, modeling \& analytical knowledge } \\
\text { and skills. }\end{array}$ & $\begin{array}{l}\text { CISY260 } \\
\text { CISY363 } \\
\text { CISY365 }\end{array}$ & & $\begin{array}{l}\text { CISY350 } \\
\text { CISY486 }\end{array}$ \\
\hline $\begin{array}{l}\text { 1. Understand quantitative and qualitative } \\
\text { aspects of knowledge }\end{array}$ & & & \\
\hline 2. Quantitatively analyze and interpret data & & & \\
\hline 3. Quantitatively create and evaluate model & & & \\
\hline $\begin{array}{l}\text { Outcome: Students will be able to solve problems } \\
\text { from a system approach }\end{array}$ & $\begin{array}{l}\text { CISY311 } \\
\text { CISY362 }\end{array}$ & $\begin{array}{l}\text { CISY305 } \\
\text { CISY430 } \\
\text { CISY444 } \\
\text { CISY464 } \\
\text { CISY466 } \\
\text { CISY467 } \\
\text { CISY480 } \\
\text { CISY486 }\end{array}$ & $\begin{array}{l}\text { CISY350 } \\
\text { CISY330 } \\
\text { CISY344 } \\
\text { CISY364 }\end{array}$ \\
\hline 1. Know the system development process & & & \\
\hline $\begin{array}{l}\text { 2. Apply systems design knowledge, } \\
\text { techniques, and skills }\end{array}$ & & & \\
\hline $\begin{array}{l}\text { Outcome: Students will acquire essential } \\
\text { programming skills }\end{array}$ & $\begin{array}{l}\text { CISY330 } \\
\text { CISY344 } \\
\text { CISY364 } \\
\text { CISY430 } \\
\text { CISY444 }\end{array}$ & $\begin{array}{l}\text { CISY466 } \\
\text { CISY305 } \\
\text { CISY480 }\end{array}$ & \\
\hline
\end{tabular}




\section{Issues in Information Systems}

Volume 14, Issue 2, pp.1-11, 2013

\begin{tabular}{|c|c|c|c|}
\hline & CISY464 & & \\
\hline 1. Understand written programs & & & \\
\hline 2. Design programs & & & \\
\hline 3. Write correct codes & & & \\
\hline 4. Execute, test and debug programs & & & \\
\hline $\begin{array}{l}\text { Outcome: Students will learn current information } \\
\text { technology issues and trends }\end{array}$ & CISY486 & $\begin{array}{l}\text { CISY } 155 \\
\text { CISY495 }\end{array}$ & $\begin{array}{l}\text { CISY311 } \\
\text { CISY350 } \\
\text { CISY466 } \\
\text { CISY467 } \\
\text { CISY480 }\end{array}$ \\
\hline 1. Know the current issues and trends & & & \\
\hline $\begin{array}{l}\text { 2. Learn to use current application and system } \\
\text { software }\end{array}$ & & & \\
\hline $\begin{array}{l}\text { Outcome: Students will be able to work effectively } \\
\text { on teams to accomplish a common goal }\end{array}$ & & $\begin{array}{l}\text { CISY350 } \\
\text { CISY480 } \\
\text { CISY466 }\end{array}$ & CISY486 \\
\hline 1. Fulfill team role's duties as assigned & & & \\
\hline 2. Listen to other teammates & & & \\
\hline $\begin{array}{l}\text { Outcome: Students will be able to express } \\
\text { themselves effectively in oral communication }\end{array}$ & & $\begin{array}{l}\text { CISY350 } \\
\text { CISY486 }\end{array}$ & \\
\hline 1. Speaking skills & & & \\
\hline 2. Knowledge understanding & & & \\
\hline $\begin{array}{l}\text { Outcome: Students will be able to express } \\
\text { themselves effectively in written communication }\end{array}$ & & $\begin{array}{l}\text { CISY350 } \\
\text { CISY363 } \\
\text { CISY365 } \\
\text { CISY486 }\end{array}$ & $\begin{array}{l}\text { CISY260 } \\
\text { CISY311 } \\
\text { CISY362 }\end{array}$ \\
\hline 1. Contents & & & \\
\hline 2. Mechanics & & & \\
\hline 3. $\quad$ Structure & & & \\
\hline $\begin{array}{l}\text { Outcome: Students will be able to understand } \\
\text { professional ethical, legal, security and social } \\
\text { issues and responsibilities }\end{array}$ & & $\begin{array}{l}\text { CISY350 } \\
\text { CISY362 } \\
\text { CISY467 } \\
\text { CISY495 }\end{array}$ & $\begin{array}{l}\text { CISY260 } \\
\text { CISY466 } \\
\text { CISY480 } \\
\text { CISY486 }\end{array}$ \\
\hline $\begin{array}{l}\text { 1. Demonstrate knowledge of professional } \\
\text { codes of ethics, legal, security and social } \\
\text { issues }\end{array}$ & & & \\
\hline $\begin{array}{l}\text { 2. Demonstrate an ethical decision making } \\
\text { process }\end{array}$ & & & \\
\hline
\end{tabular}

Appendix 2: Sample of a Course Description

\begin{tabular}{|l|l|l|l|}
\hline Dept., Number & CISY 466 & Course Title & Web Design and Implementation \\
\hline Semester hours & 3 & Course Coordinator & Dr. Bai \\
\hline & & URL (if any): & http://blackboard.vsu.edu \\
\hline
\end{tabular}

Current Catalog Description 


\section{Issues in Information Systems \\ Volume 14, Issue 2, pp.1-11, 2013}

The Internet Technologies, especially the Web based applications are transforming the way that we do business and run organizations. In this course, we will learn how to build commercial Web applications, including B2C and B2B Web applications using one of the latest server-side scripting language: JavaServer Pages (JSP). You will learn how to design and develop dynamic Web pages with JSP, and how to build database driven Web application via JSP. Also, this course will adopt a practical hands-on approach so you can apply the concepts discussed in each chapter to a real-world problem solving process. This course is aim to prepare you for Web based application design and implementation, database administration, client/server application development, and Web-based information systems development. In particular, a running case project called the Student Record Access System (SRAS) will guide you through chapters to create the whole Web application. The SRAS project will give you chance to apply the knowledge you learn in each chapter to a real Web application.

Textbook

Title: JavaServer Pages (Web Warrior Series)

Author: Xue Bai

Publisher: Thomson Course Technology

References

None

Course Goals

13. Students will recognize the impact of the global business environment on the information technology.

14. Students will recognize the value of web based information technology in today's competitive business environment

15. Students will know how to manage states and events with JSP objects.

16. Students will be familiarized with JavaServer Pages environment, including design, development, and implementation of dynamic web pages.

17. Students will know how to use JDBC to access databases without needing to worry about the specific operational details associated with a particular database type.

18. Students will master techniques to Build web pages anyone can browse.

19. Students will acquire the tools from JSP to integrate your existing information systems into new web-based applications

Prerequisites by Topic

Programming Logic and one semester of any programming language courses

Major Topics Covered in the Course

\begin{tabular}{|l|l|}
\hline Topics & Weight \\
\hline Introduction to JSP & $5 \%$ \\
HTML & $20 \%$ \\
Client-Side and Server-side scripting & $10 \%$ \\
Basic forms & $5 \%$ \\
Variables and JSP control structure & $5 \%$ \\
Scripting with JSP Elements & $5 \%$ \\
Processing the Client Request & $10 \%$ \\
Application, Sessions, and Cookies & $5 \%$ \\
JavaBeans & $5 \%$ \\
Scope of Variables and JavaBeans & $5 \%$ \\
Database with JSP & $25 \%$ \\
\hline
\end{tabular}




\section{Issues in Information Systems \\ Volume 14, Issue 2, pp.1-11, 2013}

Laboratory projects (specify number of weeks on each)

Create Web pages using HTML - 2 weeks

Create Web pages using JSP - 4 weeks

Estimate Curriculum Category Content (Semester hours)

\begin{tabular}{|l|l|l|l|l|l|}
\hline Area & Core & Advanced & Area & Core & Advanced \\
\hline Hardware and Software & & & $\begin{array}{l}\text { Networking and } \\
\text { Telecommunications }\end{array}$ & 1 & Analysis and Design \\
$\begin{array}{l}\text { Modern Programming } \\
\text { Language }\end{array}$ & 1 & & $\begin{array}{l}\text { Role of IS in an } \\
\text { Organisation }\end{array}$ & & \\
\hline Data Management & 1 & $\begin{array}{l}\text { Information Systems } \\
\text { Environnent }\end{array}$ & & \\
\hline Quantitative Analysis & & & & \\
\hline
\end{tabular}

Theoretical Foundations

Please list the types of theoretical material covered, and estimate the time devoted to such coverage.

\begin{tabular}{l|l}
\hline Programming Logic & 5 (hours) \\
HTML & 10 \\
JSP & 15 \\
Database & 10
\end{tabular}

Analysis

Please describe the analysis experiences common to all course sections.

All laboratory projects are required to analysis of problem and provide solution in programming logic form.

Design

Please describe the design experiences common to all course sections.

All laboratory projects are required to design software solution for given requirements. 